\title{
COST ANALYSIS OF MINI HYDRO POWER PLANT USING BACTERIAL SWARM OPTIMIZATION
}

\author{
Soner ÇELIKDEMIR ${ }^{1}$, Burak YILDIRIM*2, Mahmut Temel ÖZDEMIR ${ }^{3}$ \\ ${ }^{1}$ Adilcevaz Vocational School High Scholl Bitlis Eren University, Bitlis, 13100, Turkey \\ ${ }^{* 2}$ Vocational and Tech. High School Bingol University, Bingol,12100, Turkey \\ ${ }^{3}$ Department of Electrical and Electronics Engineering, Faculty of Engineering, Firat University, \\ Elazig, 23119 Turkey \\ *Corresponding author; E-mail: byildirim@bingol.edu.tr \\ According to the 2023 vision determined by Turkey, which is one of the G20 \\ countries, it aims to evaluate of the hydro power potential in terms of technical \\ and economic making medium and large hydro power plants. Turkey's mini \\ and micro hydro power potential isn't fully evaluated as a number of \\ countries. In this context, empirical formula for cost analysis of mini and \\ micro hydro power plants, which are becoming increasingly important, have \\ been developed in this work with the aim of facilitating economic analysis. \\ The developed equation is found by modified Bacterial Swarm Optimization \\ (BSO) algorithm. When analyzed with the literature data, the obtained \\ equation can calculate the costs with the least mistakes.
}

Key words: Cost of Mini and Micro Hydropower, Pelton Turbine, Bacterial Swarm Optimization

\section{Introduction}

Energy has an important role in global and socio-economic development. Today, the need for energy has increased because of the growing amount of energy used in industry, housing and agricultural activities. Energy demand is often met by conventional methods based on fossil fuels. The reduction and harmful effects on the environment of fossil fuel resources have led to sustainable and environmentally friendly energy sources.

This situation is an important criterion for the investment decision of the mini scale hydro power plant. Construction works and electro-mechanical equipments constitute a large part of the investment costs of small and mini hydro power plants. The cost of the construction work can be reasonable estimated based on the design drawings. However, the cost calculations of electro-mechanical equipment can differ from. Taking these into consideration, it is possible to make an investment decision by realistic estimation of the cost calculations of electro-mechanical equipments. 
Mishra made cost estimates using three methods (sigma algorithm, linest method and logest method) for river-type small-scale hydro power plants using power and energy parameters [1]. Cavazzini calculated the investment cost of very mini and micro hydro power plants using power, head and flow parameters for mechanical and electrical equipment costs [2]. Carapelluci examined in terms of economic, technical and potential the mini-scale hydro power plants located in the Abruzzo region of Italy [3]. Elbatran has examined low-power hydro power plants in terms of performance, operation and costs [5]. Aggdis developed new formulas to estimate power generation of small-scale hydropower plant based on local and physical characteristics of the region with empirical formulas [6]. In [7], the series of equations that determine the cost from basic parameters such as power and drop were developed and applied to the most common turbine varieties under $2 \mathrm{MW}$, pelton, francis, kaplan and semi-kaplan [7]. Signal has attempted to develop correlations for small scale hydro power plants projects [8]. In [9], the cost analysis of renewal of mini and small-scale hydro power plants examined [9]. Filho made a cost estimate using the appearance factor in a mini and small scale hydro power plant [10]. In these studies, heuristic optimization methods have been substantially used [1-19]. Heuristic optimization methods are often used to solve problems that the solution space is not determined [12-14]. Heuristic methods have been used especially for solving many problems of power systems [15-19].

$215 \mathrm{TWh} /$ year of Turkey's technical hydropower potential was adopted, but this value was last expressed at around $250 \mathrm{TWh} /$ year [19]. Thus, the economic hydroelectric potential is estimated to be $141 \mathrm{TWh} /$ year [20]. In the case of evaluation of miniand microhydro power plants (HPP), this potential will be 180-200 TWh/year [19]. The small, mini and micro HPP is foreseen to be a value close to $15 \%$ of Turkey's economically feasible power potential, and thus this potential would have a capacity of around $22 \mathrm{TWh}$ / year based on the $141 \mathrm{TWh} /$ year approach and around $29 \mathrm{TWh} /$ year based on the 193 $\mathrm{TWh} /$ year approach but the exact results are not yet clear [21-23].

When the effects of global warming on Turkey taken into consideration, technical and economic potential of hydro power of Turkey's need to be reassessed and not only the average potential but also the variable potential taken into consideration. According to the 25 -and-50-year perspective scenario, our country are reported to changes in rainfall regimes. [23-26]. In particular, it is expected that the amount of rainfall in the Black Sea region will increase. It is seen that this region with high hydraulic energy potential can now be considered as a small HPP even the lowest flow areas at the present time in energy production by taking more rainfall. The Pelton turbines, which have low specific speed and feasibility in low flow, high head region, will mostly be preferred in the black sea region which has a great slope.

In this work carried out in this context, the mini hydropower plants with Pelton type turbine in Italy, which has a geographical characteristic very close to the Black Sea region has been developed the cost function related to the cost of electro-mechanical equipment. The cost function is obtained by Bacterial Swarm Optimization (BSO), which is widely known in literature and is the hybrid structure of Partial Swarm and Bacterial Foraging Optimization algorithms, modified by the authors. The organization of the paper is as follows. In the first section, a general introduction was made and information was given on the subject. In the second section, the works and functions related to the extraction of cost calculations of hydro power plants and their cost charts are given. In the third section, 
information and application about the modified BSO are briefly given. The results obtained were compared with the literature results. In the last section, the results were evaluated.

\section{Hydropower and Plant Costs}

The pressure generated by water with a certain height in hydro power plants is first converted into mechanical energy. This energy expression is given in equation (1) [1].

$$
P=\tau \cdot \rho \cdot g \cdot Q \cdot H
$$

Where, $P$ is the mechanical power converted at the turbine shaft $(\mathrm{W}), \tau$ is the efficiency of the turbine, $\rho$ is the density of water $\left(\mathrm{kg} / \mathrm{m}^{3}\right), \mathrm{g}$ is the gravity coefficient $\left(\mathrm{m} / \mathrm{s}^{2}\right), \mathrm{Q}$ is the water flow $\left(\mathrm{m}^{3} / \mathrm{s}\right)$, and $\mathrm{h}$ is the head of water $(\mathrm{m})$.

Hydraulic turbines are the machines that turn the water flow energy into mechanic energy with the help of revolving wheels. Hydraulic turbines, which have been simply used for centuries, have been manufactured for about 150 years. Simple and small powerful water turbines developed by Fourneyron, Jonval, Henschel, Schwamkruo, Zuppinger etc. were made very quickly in the 19th century and the electricity generated by generators driven by water turbines was transported to the consumption areas in distant places by the energy transmission line made by Oscar von Miller in 1891. The transmission of the electric energy obtained from the water turbines to the distant distances with the help of the energy transmission lines has enabled the establishment of the larger and more powerful HPPs which are working in parallel with each other. However, hydraulic turbines, which can be made the automatic load-frequency adjustment, have started to spread from the 1920s. Such turbines are now widely used, and the yields of today's large powerful hydraulic turbines have increased values between $93 \%$ and $97 \%$.

In order to understand hydraulic turbines, some of the topics used in size calculations need to be expressed. The most important of these is the Specific Speed.

There are two different definitions and accounts of the concept of Specific Speed. These; The wheel working as $H=1 \mathrm{~m}$ and $Q=1 \mathrm{~m}^{3} / \mathrm{s}$, ( $H$ head, Q discharge) is the number of revolutions $n_{q}$. In practice, The $\mathrm{n}_{\mathrm{s}}$ specific speed, which is the number of revolutions of a model turbine rotor, which is geometrically similar to the actual turbine rotor to be produced and give $N_{h}=1 \mathrm{BG}$ power for $H=1 \mathrm{~m}$ useful hydraulic head, is used. Both $n_{q}$ and $n_{s}$ specific speed of revolutions constitute the basis for the turbine project together with the selection of the hydraulic turbine type and the hydraulic turbine's project values which is $Q_{n}, H_{n}$ ve $n_{n}$ values. 
Table 1. Specific Speed of Hydraulic Turbine Types

\begin{tabular}{|l|l|}
\hline Turbines & Specific Speed $\left(n_{q}\right)$ \\
\hline Pelton & $1-30$ \\
\hline Turgo & $20-70$ \\
\hline Cross-Flow & $20-130$ \\
\hline Francis & $80-400$ \\
\hline $\begin{array}{c}\text { Propeller or } \\
\text { Kaplan }\end{array}$ & $340-1000$ \\
\hline
\end{tabular}

$n_{q}=n \cdot \frac{\sqrt{\theta}}{\sqrt[4]{H^{3}}}$

$n_{s}=n \cdot \frac{\sqrt{N_{h}}}{\sqrt[4]{H^{5}}}$

$n=n_{s} \frac{H_{n}^{\frac{5}{4}}}{P^{\frac{1}{2}}} \quad(\mathrm{dev} / \mathrm{dk}$.

$H_{n}$ : Net Head (m), $P$ : Turbine power (BG), ${ }^{n}$ : Turbine Specific Speed (rotations per minute, rmp)

After the $n_{s}$ specific speed is selected, a synchronous speed suitable for the system is selected. The synchronous speed of the generator is as follows.

$$
n_{s}=\frac{60 \cdot F}{P}
$$

The speeds that can be selected in an AC system with $50 \mathrm{~Hz}$ frequency are; $3000,1500,1000$, $750,600,500,375,300,250,214,188,167,150,125,107,94,75,60$.

The most important factor in deciding on the maximum permissible head, the ratio of the number of wings on the wheel $\mathrm{B} / \mathrm{D}$ (B is the height of the mouth that gives water to the wheel, $\mathrm{D}$ is the diameter of the wheel), the expected yield, the operating condition and other information is the knowledge of the value of $n_{q}$ If $n_{q}$ is large, the probability of cavitation is high. 
Table 2. Classification of turbines according to Net Head

\begin{tabular}{|l|l|l|l|l|}
\hline Turbines & Hnet $>\mathbf{1 0 0} \mathbf{m}$ & $\mathbf{2 0}>$ Hnet $>\mathbf{1 0 0} \mathbf{m}$ & $\mathbf{5}>$ Hnet $>\mathbf{2 0 m}$ & $\mathbf{5}>$ Hnet \\
\hline Impulse & $\begin{array}{l}\text { Pelton } \\
\text { Turgo }\end{array}$ & $\begin{array}{l}\text { Cross-Flow } \\
\text { Turgo } \\
\text { Multi-Jet Pelton }\end{array}$ & $\begin{array}{l}\text { Cross-Flow } \\
\text { Multi-Jet Pelton }\end{array}$ & $\begin{array}{l}\text { water } \\
\text { wheel }\end{array}$ \\
\hline Reaction & - & $\begin{array}{l}\text { Francis } \\
\text { Pump as Turbine } \\
(\mathrm{PaT})\end{array}$ & $\begin{array}{l}\text { Propeller } \\
\text { Kaplan }\end{array}$ & $\begin{array}{l}\text { Propeller } \\
\text { Kaplan }\end{array}$ \\
& & & & \\
\hline
\end{tabular}

Hydraulic Turbines are classified as Impulse type or reaction type. Action turbines are also referred to as injection turbines and the Pelton turbine is one of them. Small powerful Pelton turbines are manufactured with horizontal axis and single-two injector (sprayer- nozzle). Pelton turbines are produced as a result of complex calculations and model experiments like many hydraulic machines. The general appearance of turbine is given in Figure 1.

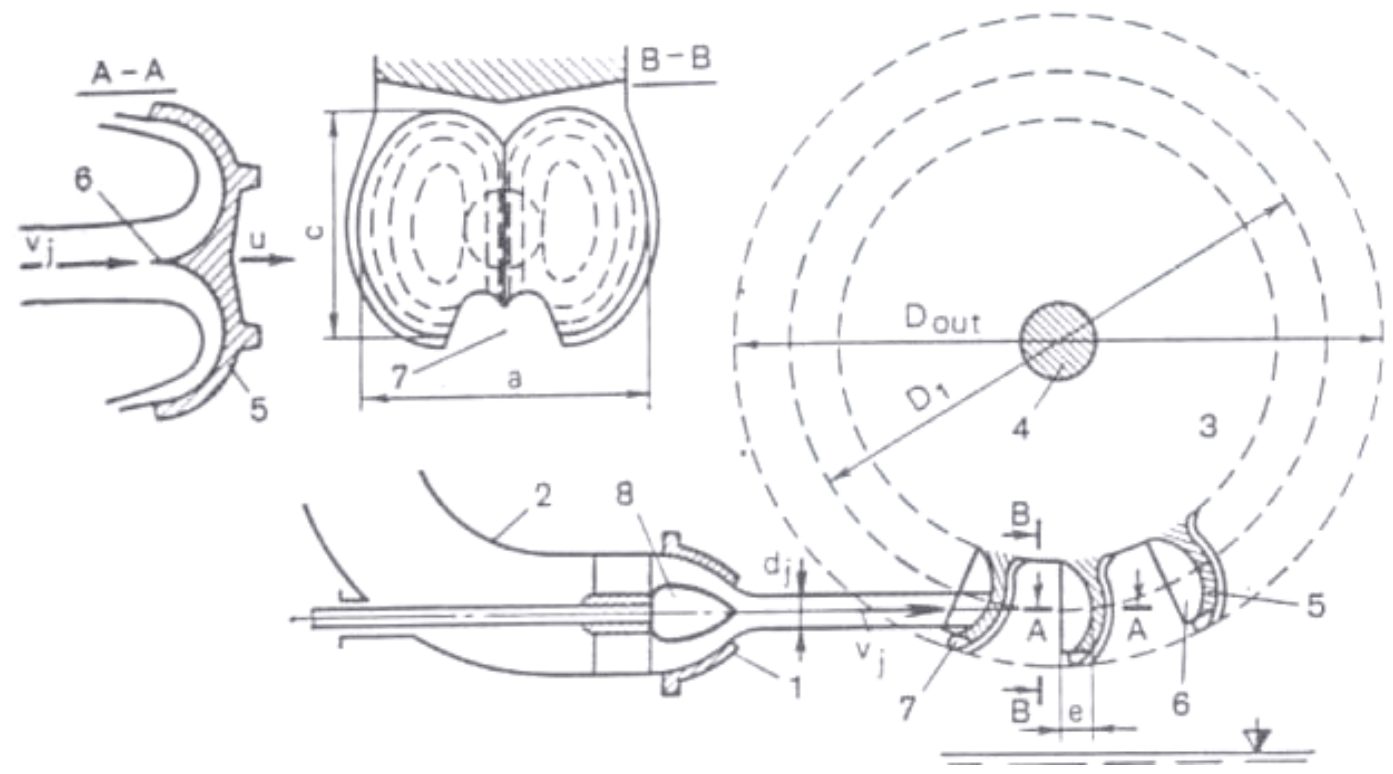

Figure 1. Pelton Turbine 


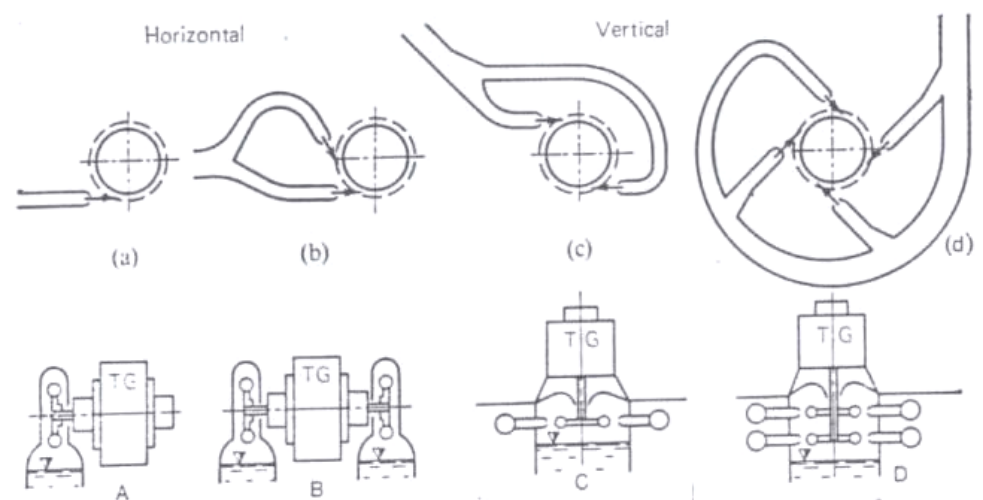

Figure 2. Pelton turbines types

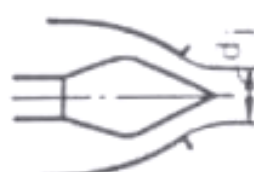

(a)

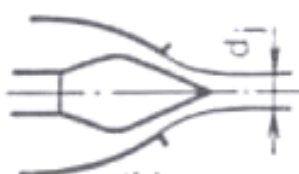

(b)

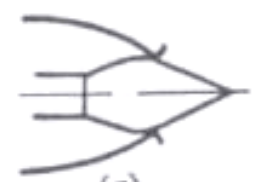

(c)

Figure 3. Adjustment of water jet speed with nozzles and needles

Hydro power plants are classified as micro (100 kW and below), mini (101 kW and $2000 \mathrm{~kW})$ and small (2001 kW and $25000 \mathrm{~kW})$ according to their power [1]. The costs of electro-mechanical equipment constitute approximately $30 \%$ to $40 \%$ of the total budget the approximate distribution is given in Figure 4 [5].

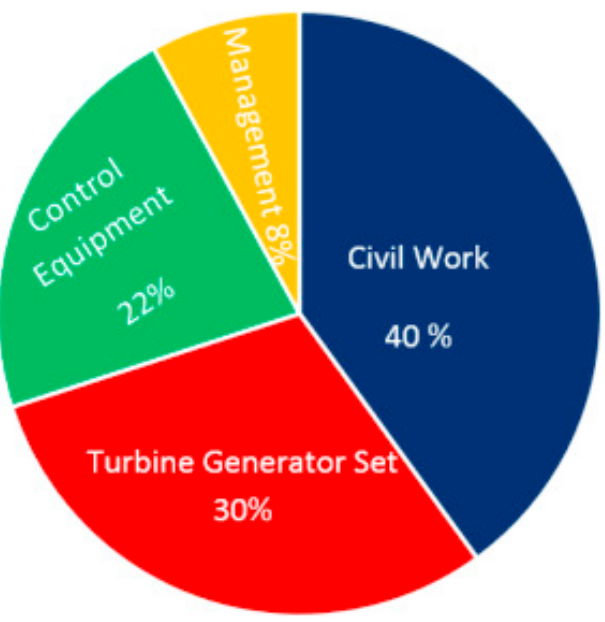

Figure 2. Cost of mini hydro power plants 
Many analytical methods of correlation have been proposed for cost accounting of electromechanical equipment from past to present day. One of these is given in equation (6).

$$
\text { Cost }=\mathrm{a} \cdot \mathrm{P}^{\mathrm{b}} \cdot \mathrm{H}^{\mathrm{c}}+\mathrm{d}
$$

In the equation $\mathrm{a}, \mathrm{b}$ and $\mathrm{c}$ are constant coefficients, $\mathrm{P}$ is power $(\mathrm{kW}), \mathrm{H}$ is gross heat $(\mathrm{m})$. The analytical correlation expressions proposed in the literature are given in Table 1.

Table 3. Electromechanical cost estimate table of small scale hydro power plants in literature

\begin{tabular}{|c|c|c|}
\hline Cost Function & Year & Authors \\
\hline $\operatorname{Cost}[\$]=9000 \cdot P^{0.7} \cdot H^{-0.35}$ & 1070 & Gordon \\
\hline & 1919 & Penman \\
\hline $\operatorname{Cost}[\$]=97436 \cdot P^{0.53} \cdot H^{-0.53}$ & 1979 & Lasu and Persson \\
\hline $\operatorname{Cost}[\$]=9600 \cdot P^{0.82} \cdot H^{-0.35}$ & 1984 & Gulliver and Dotan \\
\hline Spec. Cost $[\$ / k W]=31500 \cdot P^{0.25} \cdot H^{-0.75}$ & 1998 & Whittington et al. \\
\hline $\operatorname{Cost}[\$]=40000 \cdot P^{0.70} \cdot H^{-0.35}$ & 2000 & Voros et al. \\
\hline Spec. Cost $[€ / k W]=1000 \cdot\left(34.12+16.99 \cdot P^{0.91} \cdot H^{-0.14}\right)$ & 2000 & Chenal \\
\hline $\operatorname{Cost}[€]=20570 \cdot P^{0.70} \cdot H^{-0.35}$ & 2001 & Papantonis \\
\hline Spect. Cost $[\$ / k W]=12900 \cdot P^{0.82} \cdot H^{-0.246}$ & 2003 & Gordon \\
\hline Spect. Cost $[€ / k W]=3300 \cdot P^{-0.122} \cdot H^{-0.107}$ & 2005 & Kaldellis \\
\hline Spect.Cost $[€ / k W]=17693 . P^{-0.3644725} \cdot H^{-0.281735}$ & 2009 & Ogayar and Vidal \\
\hline $\operatorname{Cost}[€]=12000 \cdot\left(P / H^{0.2}\right)^{0.56}$ & 2010 & Aggidis et al. \\
\hline $\begin{array}{c}\operatorname{Cost}[€]=1358678 \cdot H^{0.014}+8490 \cdot Q^{0.515}+3382 . P^{0.416} \\
-1479160\end{array}$ & 2016 & Cavazzini et al. \\
\hline
\end{tabular}

Aggidis et al., who make detailed cost analysis of small and very small HPPs, examined the subject using empirical formulas [6]. This study was carried out in 2010 and the formulas were obtained by examining the costs of the plants established as of 2008. The following equations are obtained by converting to TL according to the time of the study. Where $\mathrm{P}$ is power in $\mathrm{kW}, \mathrm{H}_{\mathrm{n}}$ is net drop in $\mathrm{m}, \mathrm{Q}$ is flow in $\mathrm{m}^{3} / \mathrm{s}$.

The total project cost of the mini and micro HPP, as a function of power and net drop are as follows; 


$$
\begin{aligned}
& C_{P r}=72500 .\left(P / H^{0,35}\right)^{0,65} \text { for } 2<\mathrm{H}_{\mathrm{n}}<30 \\
& C_{P r}=131950 .\left(P / H^{0,3}\right)^{0,6} \text { for } 30<\mathrm{H}_{\mathrm{n}}<200
\end{aligned}
$$

When Equations 7 and 8 are plotted against the working zone of the mini and micro HPP, the change in Figure 5 is obtained.

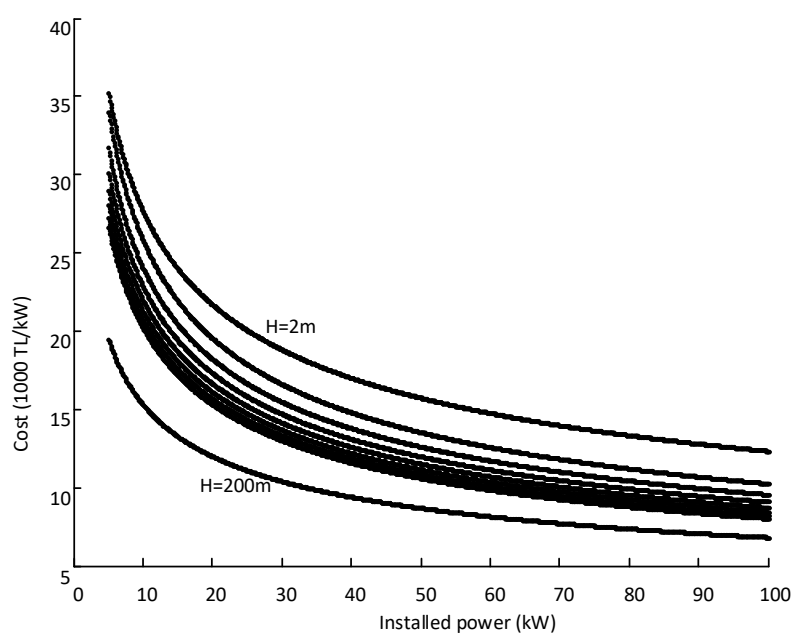

Figure 5. Electromechanical costs of mini and micro HPP according to installed power

The empirical formulas that are the function of power and net drop, derived from the cost data of the major electromechanical producers (Alstom, Andritz, Gilbert Gilkes \& Gordon Ltd, NHT and Voith Siemens) in the world in 2000 and 2008 are as follows;

$$
\begin{aligned}
& C_{E M}=20570 \cdot\left(P^{0,7} / H^{0,35}\right) \\
& C_{E M}=34800 \cdot\left(P / H^{0,2}\right)^{0,65}
\end{aligned}
$$

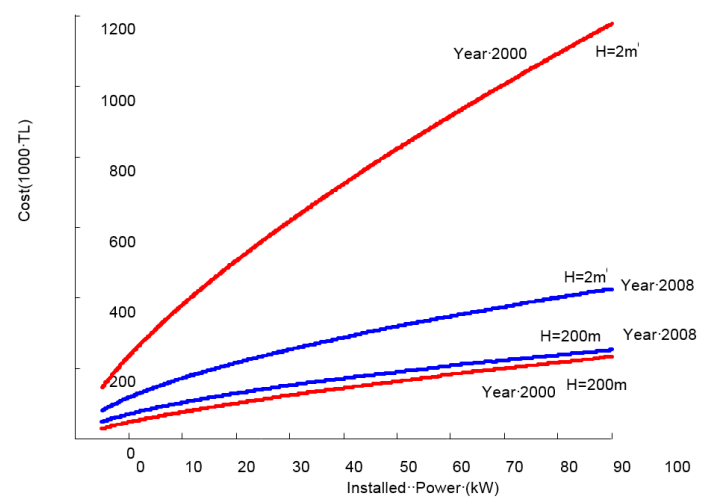

Figure 6. Turbine costs of mini and micro HPP according to Installed Power 
Equation 10 is the equations obtained according to 2008 data while Equation 9 is the equations obtained according to 2000 data. When these equations are plotted against the working region of the mini and micro HPP, the change in Figure 6 is obtained.

The formula obtained as the function of the drop and flow for kaplan turbines of $0.5 \mathrm{~m}^{3}<\mathrm{Q}<5$ $\mathrm{m}^{3}$ is given in equation 11 and the formula obtained only as the function of the power is given in equation 12. When these equations are plotted against the working region of the mini and micro HPP, the change in Figure 7 is obtained.

$$
\begin{aligned}
& C_{K 1}=43500 \cdot(Q \cdot H)^{0,68} \\
& C_{K 1}=10150 \cdot(\mathrm{P})^{0,68}
\end{aligned}
$$

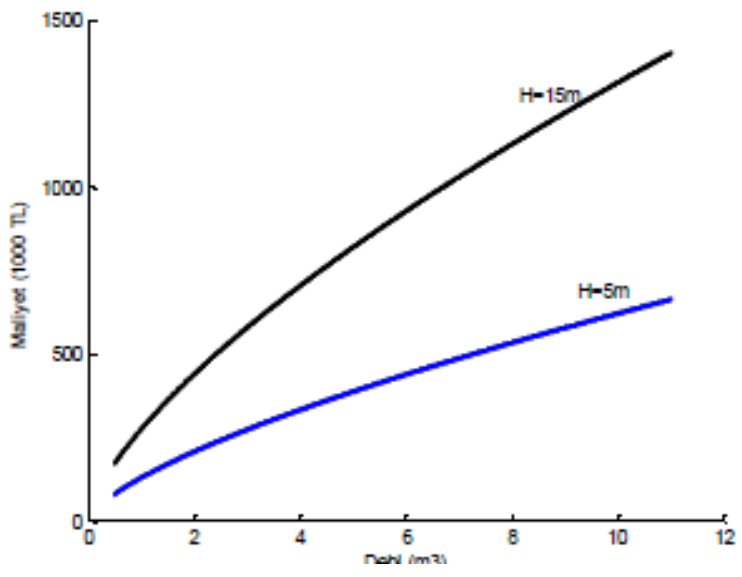

Figure 7. Costs of mini and micro HPP with kaplan turbine according to installed power

The formula obtained as the function of the head and flow for Francis turbines of $0.5 \mathrm{~m}^{3}<\mathrm{Q}<2.5$ $\mathrm{m}^{3}$ is given in equation 13 and the formula obtained only as the function of the power is given in equation 14. When these equations are plotted against the working region of the mini and micro HPP, the change in Figure 8 is obtained.

$$
\begin{aligned}
& C_{F 1}=411800 \cdot\left(Q \cdot H^{0,5}\right)^{0,07} \\
& C_{F 1}=353800 \cdot\left(P / H^{0,5}\right)^{0,07}
\end{aligned}
$$




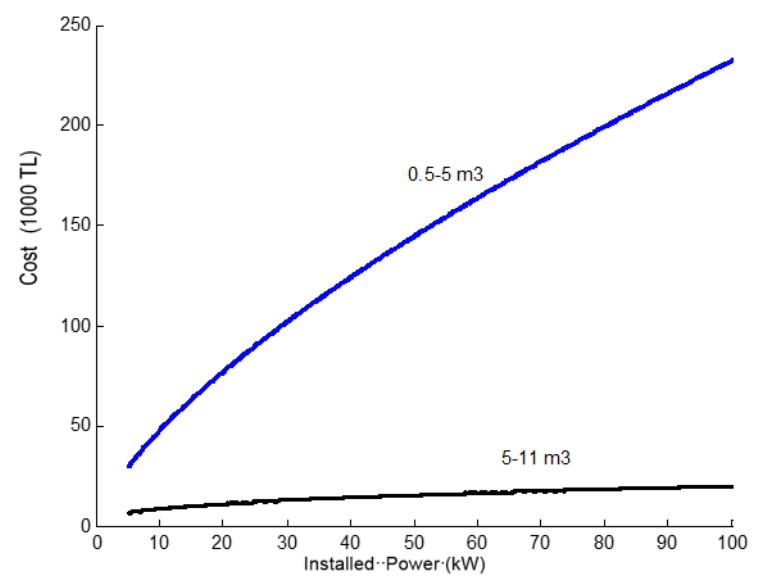

Figure 8. Costs of mini and micro HPP with francis turbine according to installed power For Francis turbines of $2.5 \mathrm{~m}^{3}<\mathrm{Q}<10 \mathrm{~m}^{3}$;

$$
\begin{aligned}
& C_{F 2}=817800 \cdot\left(Q \cdot H^{0,5}\right)^{0,11} \\
& C_{F 2}=646700 \cdot\left(P / H^{0,5}\right)^{0,11}
\end{aligned}
$$

When equations 15 and 16 are plotted against the working region of the mini and micro HPP, the change in Figure 9 is obtained.

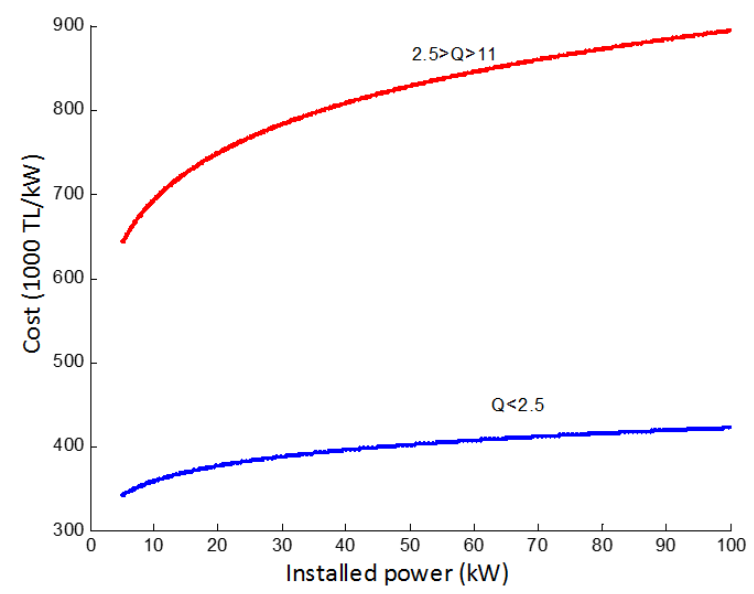

Figure 9. Costs of mini and micro HPP with francis turbine according to installed power

Equation 17 gives the cost equation according to the net drop and flow of the Pelton turbine. Equation 18 expresses the change of the system power according to cost.

$$
\begin{aligned}
& C_{P}=24070 \cdot\left(Q \cdot H^{0,5}\right)^{0,54} \\
& C_{P}=7540 \cdot(P)^{0,54}
\end{aligned}
$$


When the equations 17 and 18 for the Pelton turbines are plotted against the working zone of the mini and micro HPP, the change in Figure 10 is obtained.

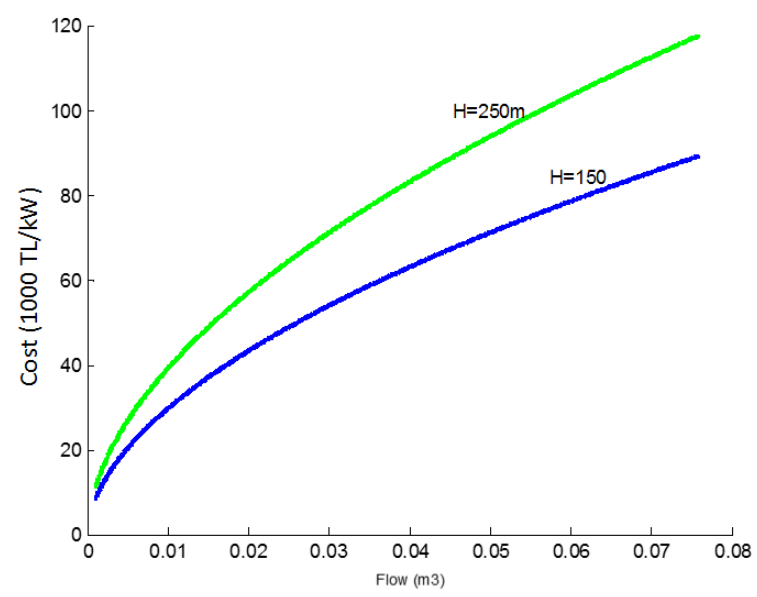

Figure 10. Costs of mini and micro HPP with Pelton Turbine according to Flow

\section{Bacterial Swarm Optimization Algorithm}

The PSO is an swarm intelligence based optimization algorithm developed by sociologistpsychologist James Kennedy and electrical engineer Russel Eberhart in 1995, inspired from the behaviours of foraging of birds and fish swarms [12]. The PSO algorithm starts with taking parts of all particles randomly in the search space and the positions of the particles are updated according to the best coordinates of itself and the best coordinates of its neighbours in each step. The search process continues to achieve the best result.

Escherichia coli bacteria, which are referred to in the BFO method, another intuitive optimization method, are microorganisms which realize the nutrition activities spending energy at the optimum level and using the abilities of limited perception and mobility [13]. The optimization cycle of the BFO algorithm consists of three events. They are chemotaxis, reproduction and elimination-dispersal. These three events are as follows:

Chemotaxis: Microbiological studies show that E. coli bacteria move with their flagellum. If all flagellum turn counter clockwise, the bacteria move forward. When all flagellum turn clockwise, the bacteria decelerates and oscillates wherever they are. Foraging of the bacteria depends on the changes between the last two behaviors.

The rotation of the flagellum in foraging process of the bacteria takes place according to the value of the environment at the time and then it is decided whether the current position will be changed or not and how the next movement (the direction and step length) will be changed in the light of some parameters.. The formula for changing direction in the BFO algorithm is as follows: 
$\theta^{i}(i+1, k, l)=\theta^{i}(i, k, l)+C(i) \varphi(j)$

Where $\theta^{i}(i+1, k, l)$, position of the $i$. bacteria shows; $\varphi(j)$ expresses the direction movement depending on the flagellum movement $j, k$, and $l$ show the indices of the chemotaxis, reproduction and elimination events; and $C(i)$ corresponds to the step length. In addition, when the bacteria reaches the nutrient, it releases a chemical substance, which has a stimulatory effect on the other bacteria. This substance ensures the other close Escherichia coli bacteria to move to the place where the bacteria, which finds nutrition, is.

Reproduction: After a foraging period, these bacteria are removed from the population due to the foraging strategies of some bacteria fail to be successful openly. Bacteria whose foraging strategy is good are duplicated in the same amount to replace the removed ones with the aim of pegging the number of the population. This process is an imitation of the segmentation of the bacteria in some way.

Elimination-Dispersal: Excessive temperature increase, rapid water fluxes and other factors in the environment where bacteria live affect the behaviors of the bacteria to a large extent. All of these factors can cause sudden or slow changes in the population. These changes may be the death of all the bacteria in that area or the dragging or migration of some of them to another area. Elimination-dispersal phenomenon is applied to imitate these biological processes This application may have a negative impact on the performance of the chemotaxis event, as well as positively affecting bacteria by dragging them closer to a better nutrient area. This application means that the bacteria moves to a new position. 


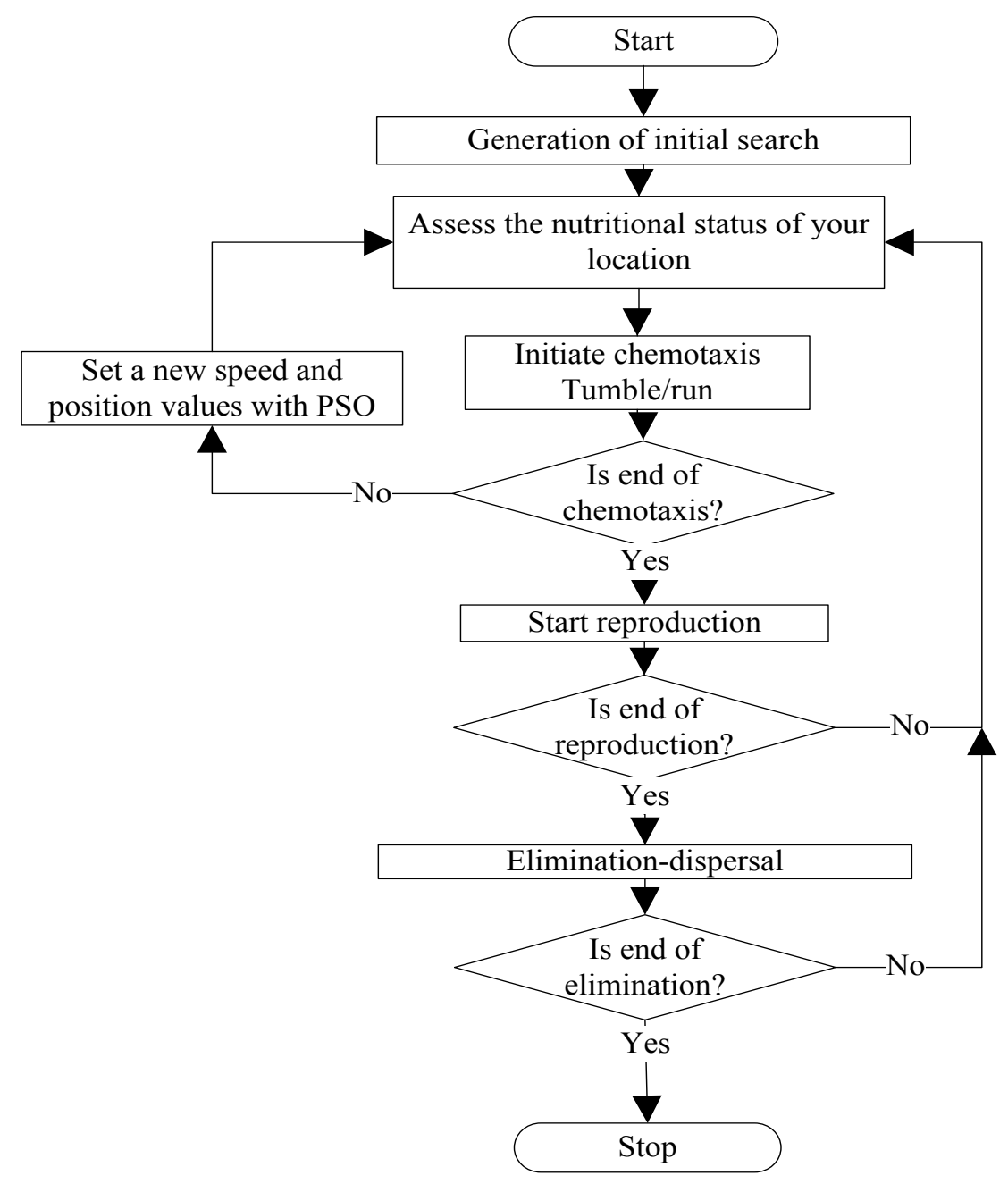

Figure 11. Flow chart for BSO algorithm

The BSO, a hybrid optimization method, has emerged as a more effective optimization method by utilizing positive characteristics of PSO's such as transferring the social information and BFO's such as determining a new direction in the elimination and disintegration process [14].

Basic steps of the BSO algorithm are as follows:

Step 1: Form the population.

Step 2: Evaluate the individuals according to the evaluation function.

Step 3: Three cycles for the optimization:

Inner loop: Chemotaxis

Calculate the information of speed and position (PSO)

Mid-loop: Reproduction

Outside loop: Elimination- Dispersal

Step 4: Decode the optimal bacterium to determine the last solution.

The direction movement of a bacteria with PSO nethod gets rid of randomness in the BSO method. Thus, process of the reaching a solution, which occurs due to the movement direction which the BFO 
determines randomly, will be shortened. The flowchart of the BSO algorithm and the program to be used in the optimization of the controller parameters in the next section are given in Figure 11.

BSO parameters: Number of bacteria $=10$; Number of chemotatic steps $=5$; Number of elimination and dispersal events $=6$; Number of reproduction steps $=4$; Probability of elimination and dispersal $=0.25$.

\section{Developed Method}

In general, different analytical correlation values have been determined for each type of turbine in accordance with the approach recommended by Ogayar and Vidal. In this study, a comparison was made with reference to the results given by Cavazzini et al.. The reference to this work is climate change, which we will see in the near future.

In the study, for the small scale hydro power plants with pelton turbines in Italy, the flow parameter was added to the equation 6 was obtained.

The actual costs in addition to the power $(\mathrm{kW})$, the drop $(\mathrm{m})$ and the flow $\left(\mathrm{m}^{3} / \mathrm{s}\right)$ of the small scale hydro power plants to which equation 2 applies are given in Table 3.

Table 4. Parameters of small scale hydro power plants with pelton turbines in Italy

\begin{tabular}{|l|l|l|l|l|l|l|l|}
\hline Plant ID & $\mathrm{P}[\mathrm{kW}]$ & $\mathrm{H}[\mathrm{m}]$ & $\mathrm{Q}[\mathrm{l} / \mathrm{s}]$ & $\begin{array}{l}\text { Real cost } \\
{[€]}\end{array}$ & $\begin{array}{l}\text { Simulated } \\
\text { cost[€] }\end{array}$ & $\begin{array}{l}\text { Simülation } \\
\text { Error [\%] }\end{array}$ & $\begin{array}{l}\text { Cavazzini } \\
\text { Error [\%] }\end{array}$ \\
\hline F.dra & 72 & 353 & 25 & 59,241 & 66,070 & $11.53 \%$ & $1.68 \%$ \\
\hline I.ra & 186 & 228 & 100 & 125,253 & 115,463 & $7.82 \%$ & $14.27 \%$ \\
\hline Val.Min. & 196 & 425 & 57 & 97,113 & 98,060 & $0.98 \%$ & $0.89 \%$ \\
\hline Chl.Alp. & 812 & 157 & 600 & 261,822 & 269,754 & $3.03 \%$ & $0.41 \%$ \\
\hline Abb.SanSal. & 515 & 275 & 230 & 173,390 & 178,796 & $3.12 \%$ & $1.30 \%$ \\
\hline Gos.da & 1088 & 467 & 284 & 220,822 & 219,320 & $0.68 \%$ & $0.75 \%$ \\
\hline Fium.ero P1 & 510 & 146 & 430 & 184,176 & 218,132 & $18.44 \%$ & $17.10 \%$ \\
\hline Fium.ero P2 & 1502 & 146 & 1255 & 381,823 & 379,213 & $0.68 \%$ & $0,39 \%$ \\
\hline Car.lio & 1017 & 409 & 300 & 203,052 & 221,288 & $8.98 \%$ & $7,93 \%$ \\
\hline Val.Min.re & 1017 & 410 & 300 & 216,690 & 221,113 & $2.04 \%$ & $1,16 \%$ \\
\hline Kat.na P1 & 604 & 264 & 276 & 213,678 & 196,149 & $8.20 \%$ & $10,29 \%$ \\
\hline Kat.na P2 & 905 & 264 & 414 & 276,667 & 240,508 & $13.07 \%$ & $14,62 \%$ \\
\hline Acq.S.ta & 109 & 45 & 300 & 157,620 & 147,515 & $6.41 \%$ & $12,55 \%$ \\
\hline & & & & & Mean & 6.536 & 6.4 \\
\hline & & & \multicolumn{2}{c}{ Standard Deviation } & 5.29 & 6.5 \\
\hline
\end{tabular}

Costs and error rates calculated by the methods developed by Cavazzini and new method are given in Table 4 and Table 5. 
Table 5. Comparison of the percentage errors between the Suggested approach and the most popular literature

\begin{tabular}{|c|c|c|c|c|c|c|c|c|c|c|c|c|c|}
\hline \multirow[t]{2}{*}{ Plant_ID } & \multirow[t]{2}{*}{$\mathbf{P}[\mathbf{k W}]$} & \multirow[t]{2}{*}{$\mathbf{H}[\mathbf{m}]$} & \multirow[t]{2}{*}{$\mathbf{Q}[1 / \mathrm{s}]$} & \multirow{2}{*}{$\begin{array}{c}\text { Real cost } \\
{[€]}\end{array}$} & $\begin{array}{l}\text { Suggested } \\
\text { Approach }\end{array}$ & Cavazzini & Ogayar, Vida & Papantonis & $\begin{array}{c}\text { Lasu, } \\
\text { Persson }\end{array}$ & $\begin{array}{c}\text { Gulliver, } \\
\text { Dotan }\end{array}$ & Kaldellis & $\begin{array}{l}\text { Gordon, } \\
\text { Penman }\end{array}$ & $\begin{array}{c}\text { Aggidis } \\
\text { et al. }\end{array}$ \\
\hline & & & & & \multicolumn{9}{|c|}{ Error [\%] } \\
\hline M.gio & 43 & 28 & 200.00 & 89000 & $-22,72 \%$ & $1.7 \%$ & $-15.1 \%$ & $0.2 \%$ & $11.3 \%$ & $-40.5 \%$ & $-36.5 \%$ & $-60.6 \%$ & $7.3 \%$ \\
\hline N.vi.lia & 351 & 140 & 250.00 & 165430 & $-10,82 \%$ & $-2.5 \%$ & $10.2 \%$ & $33.4 \%$ & $-22.3 \%$ & $1.9 \%$ & $81.7 \%$ & $-47.5 \%$ & $56.2 \%$ \\
\hline Mor.x & 1056 & 395 & 325.00 & 206700 & $-10,35 \%$ & $9.4 \%$ & $32.6 \%$ & $60.6 \%$ & $-35.7 \%$ & $40.0 \%$ & $242.3 \%$ & $-36.8 \%$ & $106.2 \%$ \\
\hline Santa Isabel & 25 & 88 & 34.13 & 35000 & $-75,95 \%$ & $-7.1 \%$ & $10.7 \%$ & $16.7 \%$ & $15.7 \%$ & $-35.1 \%$ & $-11.3 \%$ & $-54.0 \%$ & $77.1 \%$ \\
\hline Santa Isabel 2 & 30 & 88 & 40.96 & 37000 & $-79,87 \%$ & $4.5 \%$ & $17.6 \%$ & $25.4 \%$ & $20.6 \%$ & $-28.7 \%$ & $-1.5 \%$ & $-50.6 \%$ & $85.5 \%$ \\
\hline Ntra Sra de Tiscar & 58 & 85 & 81.98 & 60000 & $-50,15 \%$ & $11.7 \%$ & $11.4 \%$ & $24.2 \%$ & $7.4 \%$ & $-23.6 \%$ & $8.8 \%$ & $-51.1 \%$ & $66.1 \%$ \\
\hline Rio Frio & 80 & 155 & 62.01 & 85000 & $-2,92 \%$ & $-16.6 \%$ & $-18.6 \%$ & $-11.0 \%$ & $-34.6 \%$ & $-43.1 \%$ & $-4.5 \%$ & $-65.0 \%$ & $31.3 \%$ \\
\hline Rio Frio & 600 & 145 & 497.14 & 243408 & $2,49 \%$ & $-4.0 \%$ & $4.3 \%$ & $30.4 \%$ & $-31.2 \%$ & $6.2 \%$ & $97.0 \%$ & $-48.7 \%$ & $42.7 \%$ \\
\hline Rio Frio & 1000 & 155 & 775.11 & 390660 & $22,85 \%$ & $-23.2 \%$ & $-11.8 \%$ & $13.5 \%$ & $-45.7 \%$ & $-1.7 \%$ & $90.8 \%$ & $-55.3 \%$ & $17.5 \%$ \\
\hline Sp-P1 & 178 & 75 & 285.14 & 140001 & $-14,10 \%$ & $6.7 \%$ & $0.8 \%$ & $21.9 \%$ & $-10.9 \%$ & $-14.2 \%$ & $26.4 \%$ & $-52.0 \%$ & $35.3 \%$ \\
\hline Sp-P2 & 113 & 180 & 75.42 & 90000 & $-9,01 \%$ & $-5.9 \%$ & $-8.2 \%$ & $1.6 \%$ & $-31.5 \%$ & $-32.3 \%$ & $20.2 \%$ & $-60.0 \%$ & $47.9 \%$ \\
\hline Sp-P3 & 93 & 100 & 111.73 & 95000 & $-12,49 \%$ & $-6.8 \%$ & $-9.3 \%$ & $3.1 \%$ & $-20.1 \%$ & $-32.8 \%$ & $2.2 \%$ & $-59.4 \%$ & $34.2 \%$ \\
\hline Mata Begid & 100 & 80 & 150.18 & 120000 & $1,36 \%$ & $-16.2 \%$ & $-19.9 \%$ & $-7.1 \%$ & $-26.0 \%$ & $-39.0 \%$ & $-11.7 \%$ & $-63.4 \%$ & $13.5 \%$ \\
\hline La Toba & 190 & 80 & 285.34 & 145000 & $-11,46 \%$ & $4.5 \%$ & $-0.4 \%$ & $20.5 \%$ & $-13.9 \%$ & $-14.5 \%$ & $28.4 \%$ & $-52.6 \%$ & $34.5 \%$ \\
\hline Cerrada de Utrero & 365 & 160 & 274.07 & 169999 & $-5,37 \%$ & $1.0 \%$ & $5.9 \%$ & $27.3 \%$ & $-28.1 \%$ & $-2.3 \%$ & $80.4 \%$ & $-49.9 \%$ & $53.0 \%$ \\
\hline Cerrada de Utrero & 750 & 160 & 563.17 & 270458 & $4,81 \%$ & $-6.0 \%$ & $5.2 \%$ & $32.5 \%$ & $-33.8 \%$ & $10.9 \%$ & $113.4 \%$ & $-47.8 \%$ & $44.0 \%$ \\
\hline Acequia Hijuela de la Maja & 400 & 165 & 291.25 & 189320 & $1,94 \%$ & $-5.6 \%$ & $-0.1 \%$ & $20.6 \%$ & $-33.3 \%$ & $-6.4 \%$ & $74.9 \%$ & $-52.5 \%$ & $44.1 \%$ \\
\hline Valdepenas & 510 & 109 & 562.13 & 200002 & $-19,93 \%$ & $19.1 \%$ & $24.0 \%$ & $56.5 \%$ & $-10.6 \%$ & $25.0 \%$ & $114.3 \%$ & $-38.4 \%$ & $63.8 \%$ \\
\hline Valdepenas & 900 & 110 & 982.98 & 378639 & $15,56 \%$ & $-14.3 \%$ & $-6.3 \%$ & $22.6 \%$ & $-36.5 \%$ & $4.8 \%$ & $86.2 \%$ & $-51.7 \%$ & $18.8 \%$ \\
\hline Acequia Almegijar & 750 & 225 & 400.47 & 265050 & $13,09 \%$ & $-15.0 \%$ & $-2.5 \%$ & $20.0 \%$ & $-43.6 \%$ & $0.4 \%$ & $109.9 \%$ & $-52.7 \%$ & $41.4 \%$ \\
\hline Alhori II & 900 & 112 & 965.43 & 378639 & $16,06 \%$ & $-15.0 \%$ & $-6.7 \%$ & $21.8 \%$ & $-37.1 \%$ & $4.2 \%$ & $\mathbf{8 5 . 8 \%}$ & $-52.0 \%$ & $18.5 \%$ \\
\hline Sabinar-canarie & 1000 & 200 & 600.71 & 288490 & $3,94 \%$ & $-5.4 \%$ & $11.2 \%$ & $40.5 \%$ & $-35.8 \%$ & $21.7 \%$ & $151.4 \%$ & $-44.7 \%$ & $54.6 \%$ \\
\hline Sabinar 2-canarie & 1000 & 300 & 400.47 & 265050 & $8,44 \%$ & $-10.2 \%$ & $7.9 \%$ & $32.7 \%$ & $-43.6 \%$ & $14.9 \%$ & $162.0 \%$ & $-47.7 \%$ & $60.9 \%$ \\
\hline Mor 1-Morocco & 200 & 90 & 266.98 & 155000 & $-3,03 \%$ & $-3.7 \%$ & $-6.8 \%$ & $12.1 \%$ & $-22.3 \%$ & $-20.0 \%$ & $24.1 \%$ & $-55.9 \%$ & $27.8 \%$ \\
\hline Manteigas-Portugal & 300 & 178 & 202.49 & 174900 & $10,15 \%$ & $-15.0 \%$ & $-11.8 \%$ & $3.9 \%$ & $-40.5 \%$ & $-22.1 \%$ & $45.9 \%$ & $-59.1 \%$ & $31.7 \%$ \\
\hline Cartignano-Italy & 300 & 150 & 240.28 & 170100 & $2,47 \%$ & $-7.5 \%$ & $-4.9 \%$ & $13.5 \%$ & $-33.0 \%$ & $-15.0 \%$ & $52.8 \%$ & $-55.3 \%$ & $38.0 \%$ \\
\hline & Mean & & & & $-8,65 \%$ & $9.2 \%$ & $10.2 \%$ & $20.8 \%$ & $28.5 \%$ & $18.2 \%$ & $61.0 \%$ & $53.0 \%$ & $42.7 \%$ \\
\hline
\end{tabular}




\section{Conclusion}

The studies on size and cost analysis of both grid-connected and island plants has focused in recent years. Evaluation plan of the entire HPP potential among the close targets of Turkey motivated the authors to do this work. For this purpose, The last studies in the literature and the results of the developed equation are given in tabular form. The obtained results has been found with reference to 13 plants in Italy with the reason of geographical similarity. When the costs of the plants in Italy are calculated, it is seen that the average values of the errors are leastwise higher than the studies which done last and compared to the tables. The small standard deviation indicates that the data are scattered near the average, while large standard deviation indicates that the data are scattered at distant locations. The standard deviation value in the obtained results is smaller in this study, and according to this result, the deviation in this study is less than the other studies.. When the same equation is made for 26 pelton turbine plants around the world, much better results have been obtained than the studies so far.

\section{References}

[1] Mishra, S., et al., Approach for Cost Determination of Electro-Mechanical Equipment in RoR SHP Projects, Smart Grid and Renewable Energy, (2011), 2, pp. 63-67.

[2] Cavazzini, G., et al., Accurate Estimation Model for Small and Micro Hydropower Plants Costs in Hybrid Energy Systems Modelling, Energy 103, (2016), pp. 746-757.

[3] Carapellucci, R., et al., Techno-Economic Evaluation os Small-Hydro Power Plants: Modelling and Characterisation of the Abruzzo region in Italy, Renewable Energy 75, (2015), pp. 395-406.

[4] Mishra, S., et al., Costing of a Small Hydropower Projects, IACSIT International Journal of Engineering and Technology, Vol. 4, No. 3, June 2012, pp. 239-242.

[5] Elbatran, A. H., et al., Operation, Performance and economic Analysis of low Head MicroHydropower Turbines for Rural and Remote Areas: A Review, Renewable and Sustainable Energy Reviews 43, (2015), pp. 40-50.

[6] Aggdis, G. A., et. al., The Costs of Small-Scale Hydro Power Production: Impact on the Development of Existing Potential, Renewable Energy 35, (2010), pp. 2632-2638.

[7] Ogayar, B., et. al., Cost Determination of the Electro-Mechanical Equipment of a Small HydroPower Plant, Renewable Energy 34, (2009), pp. 6-13.

[8] Singal, S. K., et. al., analysis for Cost Estimation of low Head Run-of-River Small Hydropower Schemes, Energy for Sustainable Development 14, (2010), pp. 117-126.

[9] Ogayar, B., et. al., Analysis of the Cost for the Refurbishment of Small Hydropower Plants, Renewable Energy 34, (2009), pp. 2501-2509. 
[10] Filho, G. L. T., et. al., Cost Estimate of Small Hydroelectric Power Plants Based on the Aspect Factor, Renewable and Sustainable Energy Reviews 77, (2017), pp. 229-238.

[11] Özdemir, M.T., et al., Tuning of Optimal Classical and Fractional Order PID Parameters for Automatic Generation Control Based on the Bacterial Swarm Optimization. In: IFACPapersOnLine, (2015), pp. 501-506.

[12] Eberhart, R. C., et. al., A New Optimizer Using Particle Swarm Theory. In Proceedings of the Sixth International Symposium on Micro Machine and Human Science Vol. 1, 1995, pp. 39-43.

[13] Passino, K. M., Biomimicry of bacterial foraging for distributed optimization and control. Control Systems, IEEE, 22, 3, (2002), pp. 52-67.

[14] Korani, W.M., et. al., Bacterial foraging oriented by particle swarm optimization strategy for PID tuning. IEEE International Symposium in Computational Intelligence in Robotics and Automation (CIRA), IEEE, (2009), pp. 445-450.

[15] Öztürk, D, et. al., Load-Frequency Optimization With Heuristic Techniques In A Autonomous Hybrid Ac Microgrid, International Journal Of Energy And Smart Grid 2, (2017), pp. 2-16

[16] Çelik, V., et al., The effects on stability region of the fractional-order PI controller for one-area time-delayed load--frequency control systems. Transactions of the Institute of Measurement and Control, (2017), Volume: 39 issue: 10, page(s): 1509-1521

[17] Özdemir, M.T.,et. al., Optimal Load frequency control in two area power systems with Optics Inspired Optimization. Firat Universitesi Muhendislik Bilimleri Dergisi, 2, (2016), 28, pp. 5766.

[18] Özdemir, M.T., et. al., Comparative Performance Analysis of Optimal PID Parameters Tuning Based on the Optics Inspired Optimization Methods for Automatic Generation Control. Energies (2017), 10, 2134.

[19] Eroğlu, V., Tek Sorun Para, Global Enerji, Say1 19, (2006), pp. 26-29.

[20] Basmacı, E., Enerji Darboğazo ve Hidroelektrik Santallerimiz, DSI Vakfi Yayını, (2006).

[21] Gürbüz, A., et. al., Sustainable Energy Supply Studies in Turkey and the Role Eie, International Congress on River Basin Management, 22 to 24 March 2007, Antalya.

[22] Özdemir, M.T., et. al., Türkiye'nin Enerji Politikasında Küçük ve Çok Küçük Hidroelektrik Santrallerin Yeri ve Önemi, ICANAS 38, 10-15 Eylül 2007, Ankara, Türkiye

[23] Özdemir, M.T., et al., An Experimental System for Electrical and Mechanical Education: Micro Hydro Power Plant Prototype. Procedia-Social and Behavioral Sciences, 47, (2012), pp. 2114 2119. 
[24] Clarke, A. W., et. al., Surveys of Energy Resources, Oxford, Published by Elsevier 1td, (2004), pp.464.

[25] Priddle, R., World Energy Outlook 2001, The International Energy Agency (IEA) France, (2001) pp. 422.

[26] Ünsal, İ., Turkey's Hydroelectric Potential And Energy Policies, Stradigma E-Journal of Strategy and Analysis, Issue 6 july 2003, www.stradigma.com. 